\title{
Apical sealing of root canal fillings performed with five different endodontic sealers: analysis by fluid filtration
}

\author{
Bruno Carvalho de VASCONCELOS ${ }^{1,2}$, Ricardo Affonso BERNARDES 3,4, Marco Antonio Húngaro DUARTE ${ }^{4}$, \\ Clóvis Monteiro BRAMANTE ${ }^{4}$, Ivaldo Gomes de MORAES ${ }^{4}$ \\ 1- DDS, MSc, Sobral School of Dentistry, Federal University of Ceará, Sobral, CE, Brazil.
2- DDS, MSc, Department of Operative Dentistry, Endodontics and Dental Materials, Bauru School of Dentistry, University of São Paulo, Bauru, SP, Brazil.
3- DDS, MSc, PhD, Department of Endodontics, CPO SL Mandic, Brasiliense Dental School, Brasília, DF, Brazil.
4- DDS, MSc, PhD, Department of Operative Dentistry, Endodontics and Dental Materials, Bauru School of Dentistry, University of São Paulo, Bauru, SP, Brazil.
}

Corresponding address: Bruno Carvalho de Vasconcelos - UFC - Ceará / ABO - Ceará - Departamento de Endodontia - Rua Gonçalves Ledo, 1630 - $60110-$ 261 - Bairro JoaquimTávora - Fortaleza, Ceará - Brazil - Phone: +55-85-3242-1329 - Cel: +55-85-9995-5356 - Fax: +55-85-3281-4340 - e-mail: bcv@ufc.br.

Received: March 15, 2009 - Modification: April 09, 2010 - Accepted: October 26, 2010

\section{ABSTRACT}

\begin{abstract}
O bjectives: To evaluate the sealing ability of five root canal sealers, including two experimental cements (MBP and MTA-Obtura) using the fluid filtration method. Material and Methods: Teeth were divided into 5 study groups: G1-AH Plus; G2-Acroseal; G3Sealapex; G4-MBP; G5-MTA-Obtura; and two controls. Chemical-mechanical preparation was performed with ProFile rotary nickel-titanium instruments $1 \mathrm{~mm}$ short of the apical foramen. The sealing ability was evaluated by fluid filtration at 15, 30, and 60 days. Results: The statistical analysis showed significant difference between the materials at different periods $(p<0.05)$. AH Plus and MBP had similar leakage values at 15 and 60 days, alternating with significant reduction at 30 days, while the other materials showed progressive increase in leakage values. Acroseal and Sealapex presented the best results at 15 days and the worst at 60 days. Conclusions: All sealers evaluated presented fluid leakage, with AH Plus and MBP showing the best results at the end of the experimental period. Acroseal, Sealapex, and MTA-Obtura presented increase in leakage values at longer observation periods.
\end{abstract}

Key words: Endodontics. Root canal obturation. Root canal filling materials. Leakage. Filtration.

\section{INTRODUCTION}

Endodontic obturation comprises complete three-dimensional filling of the root canal system with materials that exhibit satisfactory physical and biological properties ${ }^{4,22}$. Ideally, the filling material should adequately seal the root canal and simultaneously prevent fluid percolation into the root canal space, stimulate the resolution of periapical pathologies, and encourage deposition of cementum to achieve biological seal20,22,25.

Filling materials should meet several requirements, such as biocompatibility, antibacterial properties, dimensional stability, radiopacity, ease of manipulation, insolubility in oral fluids, and adaptability to the root canal walls ${ }^{2}$, as well as ability to produce a hermetical seal. However, none of the currently available materials features all characteristics of the ideal sealer ${ }^{11,14}$. Every year, a great number of new endodontic filling materials are developed ${ }^{7,11}$ with hopes of revolutionizing the endodontic obturation technique ${ }^{23}$, but none of these materials have presented better results than the association of gutta-percha with conventional sealers ${ }^{12,28}$.

Resin-based endodontic cements have received considerable attention from endodontists due to their good physical-chemical ${ }^{10,11}$ and biological properties $^{17}$. On the other hand, other sealers, namely those based on calcium hydroxide or calcium oxide $^{7,15}$ or mineral trioxide aggregate (MTA) ${ }^{28}$, present yet better biological properties. With this 
in mind, the incorporation of calcium hydroxide to resin-based cements has been proposed in order to improve their biological properties ${ }^{16}$. Acroseal and MBP (experimental cement) are examples of these newer materials, which are essentially resinbased but contain a considerable amount of calcium hydroxide in their formulations $8,10,24$

MTA is highly biocompatible when used in pulpotomies $^{9}$, root perforations ${ }^{13}$, and retrograde obturations ${ }^{1}$. However, due to its difficult manipulation and insertion, it is not routinely employed as a root canal filling material ${ }^{18}$. More recently, in an effort to incorporate the desirable biological properties of MTA into an easy to manipulate and to insert material, some manufacturers have added specific components to MTA-based cements. Some examples of materials resulting from this attempt are ProRoot Endo Sealer (Dentsply Tulsa Dental Specialites, Dentsply/ Maillefer, Ballaigues, Switzerland), C.P.M. Sealer (E.G.E.O. SRL, MTM Argentina S.A., Buenos Aires, Argentina), and MTA-Obtura (Angelus, Angelus Odontológica, Londrina, PR, Brazil).

Presently, the literature is scarce on studies evaluating the physical and chemical properties of these new MTA-based sealers, as well as on the sealing ability of resin-based cements with the addition of calcium hydroxide (Acroseal and MBP). Therefore, the goal of the present study was to analyze the sealing ability of root canal fillings performed with gutta-percha and two resin-based cements with the addition of calcium hydroxide (Acroseal and MBP), and with an MTA-based sealer (MTA-Obtura), while simultaneously comparing the performance of these materials with conventional sealers (AH Plus and Sealapex) by the fluid filtration method at observation periods of 15,30 , and 60 days.

\section{MATERIAL AND METHODS}

The study sample comprised 66 freshly extracted human mandibular premolars. Teeth with multiple canals, resorptions, fractures, and/or incomplete apex formation were excluded from the sample. This project was approved by the University Ethics Committee prior to the beginning of the experiments.

After coronal access, pulp remnants were removed with a \#10 K-file (Dentsply, Dentsply/ Maillefer, Ballaigues, Switzerland) and the presence of a single root canal was confirmed. The canals were initially explored using \#15 hand-held K-files (Dentsply, Dentsply/Maillefer, Ballaigues, Switzerland). Subsequently, teeth were numbered and their real canal lengths were determined by manually inserting \#15 K-files into the canals, until the instrument tips were visible at the apical foramen with the aid of a clinical microscope (DF Vasconcellos, DF Vasconcellos, São Paulo, SP, Brazil) at 5x magnifying power. Working length was established $1.0 \mathrm{~mm}$ short of the real root canal length. When assessing the working length, roots showing lack of apical patency or foramens with diameter greater than $200 \mu \mathrm{m}$ were replaced.

Before proceeding to the biomechanical preparation of the canals, all apical foramens were standardized with a \#25 hand-held K-file. Following that, crown-down instrumentation was carried out using rotary nickel-titanium ProFile Orifice Shapers and instruments (Dentsply, Dentsply/Maillefer, Ballaigues, Switzerland) until a \#40/0.06 file was able to reach working length. At each file change, canals were irrigated with $1.0 \mathrm{~mL}$ of $2.5 \% \mathrm{NaOCl}$ (Biodinamica, Biodinamica Química e Farmaceutica LTDA, Ibiporã, PR, Brazil). After instrumentation was completed, $3.0 \mathrm{~mL}$ of $17 \%$ EDTA (Biodinamica, Biodinamica Química e Farmaceutica LTDA, Ibiporã, PR, Brazil) were introduced and allowed to remain in the canals for 3 minutes. Next, a final flush with 1.0 $\mathrm{mL}$ of $\mathrm{NaOCl}$ followed by $5.0 \mathrm{~mL}$ of saline (Farmence Farmence Laboratórios, Fortaleza, CE, Brazil) was performed. Before obturating the canals, the crowns of the teeth were removed by sectioning with a diamond disk attached to an Isomet saw (Buehler, Buehler LTD, Lake Buff, IL, USA) at 300 rpm under irrigation, in order to standardize all specimens to a length of $17.0 \mathrm{~mm}$. The root canals were then dried with paper points (Dentsply, Dentsply/ Maillefer, Ballaigues, Switzerland) and randomly divided into five study groups $(n=12)$ and two controls, one positive and one negative $(n=3)$, as follows: G1 - AH Plus (Dentsply, Dentsply/DeTrey, Konstanz, Germany); G2 - Acroseal (Septodont, Septodont Specialités, Saint-Maur des Fosses, France); G3 - Sealapex (Sybron Endo, Sybron Endo Specialities, Glendona, CA, USA); G4 - MBP (Bauru School of Dentistry-USP, Bauru, SP, Brazil); G5 - MTA-Obtura (Angelus, Angelus Odontológica, Londrina, PR, Brazil). Teeth in the positive control group were obturated with gutta-percha cones and no sealer, while those in the negative control were obturated in a manner similar to that described for G1 through G5.

All canals were filled with a single tapered gutta-percha cone \#40/0.06 (Dentsply, Dentsply/ Maillefer, Ballaigues, Switzerland). The sealers were manipulated according to manufacturers' instructions and placed into the root canals with the aid of a \#4 Lentulo spiral (Dentsply, Dentsply/ Maillefer, Ballaigues, Switzerland) introduced 5.0 $\mathrm{mm}$ short of the working length and always carrying same amount of sealer. After that, the guttapercha point was introduced up to the working length; the sealer extruded through the foramen was gently removed from the root surface with 
Table 1- Fluid filtration medians, means and standard deviation (sd) at 15, 30 and 60 days

\begin{tabular}{|c|c|c|c|c|c|c|c|c|c|}
\hline \multirow[t]{3}{*}{ Sealers } & \multicolumn{9}{|c|}{ Periods } \\
\hline & \multicolumn{3}{|c|}{15 days } & \multicolumn{3}{|c|}{30 days } & \multicolumn{3}{|c|}{60 days } \\
\hline & Median & Mean & s.d. & Median & Mean & s.d. & Median & Mean & s.d. \\
\hline AH Plus & 0.53 & $0.55^{\mathrm{b} ; * *}$ & \pm 0.27 & 0.13 & $0.14^{\mathrm{a} ; *}$ & \pm 0.11 & 0.53 & $0.55^{\mathrm{ab} ; * *}$ & \pm 0.22 \\
\hline Acroseal & 0.26 & $0.32^{\mathrm{ab} ;{ }^{*}}$ & \pm 0.23 & 1.06 & $1.46^{\mathrm{b} ; * \star}$ & \pm 1.43 & 0.73 & $1.47^{\mathrm{c} ; * *}$ & \pm 1.34 \\
\hline Sealapex & 0.26 & $0.26^{\mathrm{a}^{* *}}$ & \pm 0.12 & 0.53 & $0.75^{\mathrm{b} ; *, * *}$ & \pm 0.56 & 0.93 & $1.36^{\mathrm{bc} ; * *}$ & \pm 1.24 \\
\hline MBP & 0.46 & $0.54^{\mathrm{ab} ; * *}$ & \pm 0.30 & 0.19 & $0.17^{a ; *}$ & \pm 0.16 & 0.53 & $0.48^{\mathrm{a} ; * *}$ & \pm 0.15 \\
\hline MTA-Obtura & 0.26 & $0.44^{\mathrm{ab} ; *}$ & \pm 0.46 & 0.40 & $0.45^{\mathrm{ab} ; *}$ & \pm 0.34 & 0.93 & $1.21^{\mathrm{bc} ; * *}$ & \pm 0.87 \\
\hline
\end{tabular}

Different letters indicate statistically significant differences between sealers considering the periods (table columns) according to the Miller test $(p<0.05)$;

Different number of * indicates statistically differences between periods considering each sealer (table lines) according to the Friedman test $(p<0.05)$.

gauze. Coronal access was sealed with Cimpat (Septodont, Septodont Specialités, Saint-Maur des Fosses, France) and teeth were kept in an oven at $37^{\circ} \mathrm{C}$ and $100 \%$ relative humidity throughout the study period. After 14 days, the specimens in the experimental and in the positive control groups had the external root surfaces completely covered with epoxy glue (Araldite, Brascola, São Paulo, SP, Brazil) and two coats of nail polish (Colorama, L'Oréal, São Paulo, SP, Brazil), except for an area of $1.0 \mathrm{~mm}$ around the root apex. The specimens in the negative control group had their root surfaces completely covered.

Leakage was evaluated by the fluid filtration method employing a pressure equivalent to $10 \mathrm{psi}$, as described by Derkson, et al. ${ }^{5}(1986)$ and adapted for Endodontics by Wu and Wesselink ${ }^{30}$ (1993). Four measurements were recorded for each sample at 2-minute intervals for a total of 8 minutes at 15, 30, and 60 days after filling. The amount of leakage was expressed as $\mu \mathrm{L} / \mathrm{min}^{-1} .10$ psi. Global comparisons between the different cements at each period were analyzed by the Kruskal-Wallis test; whenever significant difference was detected, individual comparison was performed by the Miller test. Results for each cement at different periods were compared by the Friedman test. The significance level was set at $5 \%$ for all tests.

\section{RESULTS}

The mean and median leakage values, and standard deviations for the different sealers are expressed in Table 1. Comparison between materials at the 15 -day period revealed significant difference only between AH Plus and Sealapex. At the 30-day period, there were significant differences between Acroseal X AH Plus, Acroseal X MBP, AH Plus X Sealapex, and MBP X Sealapex. At the 60-day period, significant differences were observed for the following comparisons: Acroseal X MBP, Acroseal X
AH Plus, MBP X MTA-Obtura, and MBP X Sealapex.

Regarding the comparisons between periods for each cement, significant differences were observed for AH Plus and MBP between 15 and 30 days and between 30 and 60 days. For Acroseal, significant differences were found between the 15 -day period compared to the 30 and 60-day periods. Sealapex showed significant difference only between the 15 and 60-day periods. As for MTA-Obtura, significant differences were observed between 15 and 60 days and between 30 and 60 days.

\section{DISCUSSION}

Achieving a hermetic seal by entirely filling the root canal space decreases the risk that microorganisms left in the canal might come in contact with oral or periapical fluids, a potential source of nutrition. This could lead to failure in the endodontic therapy, even years after treatment is completed ${ }^{20}$. Based on these facts, leakage studies are of crucial importance to evaluate the different factors involved in the process of root canal obturation.

Several methodologies have been proposed to establish the sealing ability of filling materials, such as linear dye leakage, polymicrobial leakage, diaphanization, radioisotope labeling and the electrochemical method ${ }^{10}$. Currently, the most widely accepted method is fluid filtration, proposed by Derkson, et al. ${ }^{5}$ (1986). This method, employed to establish the sealing ability of restorative materials by quantifying dentin permeability, was adapted by Wu and Wesselink ${ }^{30}$ (1993) for Endodontics. The main advantage of the fluid filtration technique is the possibility of preserving the specimens after each assay, allowing analysis at different study periods. Moreover, this method has proven to be sensitive and reproducible ${ }^{10}$.

In attempt to assure the uniformity of the specimens, teeth had their lengths and foramen 
diameter standardized. Preparation with rotary endodontic files and obturation with a single-cone method using a tapered gutta-percha cone were also adopted in order to more closely simulate clinical procedures and to minimize operator' variability ${ }^{10}$.

Analysis of the results for the different sealers revealed that although Sealapex had the lowest leakage values at 15 days, progressive increase was observed at 30 and 60 days, similarly to Acroseal and MTA-Obtura (Table 1). Sealapex has been employed since the 1980s. It presents volumetric expansion during setting due to water sorption caused by the presence of calcium oxide; this characteristic may increase its solubility, thus raising the risk of leakage over time. Other authors have also reported greater leakage values for this sealer ${ }^{12,21}$.

Acroseal contains an antiseptic (methenamine) and an anti-inflammatory drug (enoxolone) in addition to DGEBA epoxy resin and calcium hydroxide. Among the sealers investigated in this study, it presented the greatest leakage at 30 and 60 days. Previous studies refer to its moderate toxicity within acceptable clinical standards ${ }^{15}$ and adequate flowability and radiopacity, in accordance with ADA regulations ${ }^{8,10}$. However, no investigations have addressed its sealing ability in order to allow comparison with the results from the present study. Eldeniz and rstavik $^{6}$ (2009) and Pinheiro, et al. ${ }^{19}$ (2009) evaluated the sealing ability of Acroseal against bacterial leakage and observed satisfactory results, which differ from our observations. This divergence may be explained by the presence of methenamine and calcium hydroxide, substances with proven antiseptic potential, which may have hindered bacterial penetration in the above mentioned studies.

No previous information was found in the literature regarding the sealing ability of MTAObtura. This sealer was developed by replacing saline with a liquid resin as cure initiator. The composition of the powder in this cement is similar to gray MTA Angelus, consisting of Portland cement clinker and bismuth oxide. The development of MTA-Obtura aimed at the achievement of an endodontic sealer combining the biological and sealing properties of MTA. This sealer presented very stable leakage values at 15 and 30 days, as expected for an MTA-based material. Its performance reproduced the good sealing ability of MTA as repair material ${ }^{26,27}$. However, at 60 days MTA-Obtura exhibited a considerable increase in leakage.

MBP sealer, an experimental material developed in the Department of Endodontics of the Bauru School of Dentistry, showed similar results to $\mathrm{AH}$ Plus, at all observation periods. At 15 days, $\mathrm{AH}$
Plus and MBP presented greater leakage values in comparison with the other materials evaluated. Nevertheless, these values remained stable throughout the experimental periods, differently from what was observed for Sealapex, Acroseal, and MTA-Obtura, which showed progressive increase in leakage over more extended experimental periods. At 60 days, $\mathrm{AH}$ Plus and MBP presented the lowest leakage values. These results are in agreement with previous reports for AH-Plus, which is known for its excellent sealing ability ${ }^{3,29}$.

\section{CONCLUSIONS}

While all the sealers evaluated allowed fluid leakage, AH Plus and MBP showed the best results at longer observation periods. Acroseal, Sealapex, and MTA-Obtura showed progressively increased leakage over extended experimental periods.

\section{REFERENCES}

1- Bernabe PF, Holland R, Morandi R, Souza V, Nery MJ, Otoboni Filho JA, et al. Comparative study of MTA and other materials in retrofilling of pulpless dogs' teeth. Braz Dent J. 2005;16:149-55.

2- Caicedo R, Von Fraunhofer JA. The properties of endodontic sealer cements. J Endod. 1988;14:527-34.

3- De-Deus G, Coutinho-Filho T, Reis C, Murad C, Paciornik S. Polymicrobial leakage of four root canal sealers at two different thicknesses. J Endod. 2006;32:998-1001.

4- Desai S, Chandler N. Calcium hydroxide-based root canal sealers: a review. J Endod. 2009;35:475-80.

5- Derkson GD, Pashley DH, Derkson ME. Microleakage measurement of selected restorative materials: a new in vitro method. J Prosth Dent. 1986;56:435-40.

6- Eldeniz AU, Ørstavik D. A laboratory assessment of coronal bacterial leakage in root canals filled with new and conventional sealers. Int Endod J. 2009;42:303-12.

7- Gomes-Filho JE, Bernabé PF, Nery MJ, Otoboni-Filho JA, DezanJúnior E, Moraes Costa MM, et al. Reaction of rat connective tissue to a new calcium hydroxide-based sealer. Oral Surg Oral Med Oral Pathol Oral Radiol Endod. 2008;106:e71-6.

8- Guerreiro-Tanomaru JM, Duarte MA, Gonçalves M, TanomaruFilho $M$. Radiopacity evaluation of root canal sealers containing calcium hydroxide and MTA. Braz Dent J. 2009;20:22-6.

9- Holland R, Souza V, Murata SS, Nery MJ, Bernabe PF, OtoboniFilho JA, et al. Healing process of dog dental pulp after pulpotomy and pulp covering with mineral trioxide aggregate or Portland cement. Braz Dent J. 2001;12:109-13.

10- Kardon BP, Kuttler S, Hardigan P, Dorn SO. An in vitro evaluation of the sealing ability of a new root-canal-obturation system. J Endod. 2003;29:658-61.

11- Kim YK, Grandini S, Ames JM, Gu L, Kim SK, Pashley DH, et al. Critical review on metacrilate resin-based root canal sealers. J Endod. 2010;36:383-99.

12- Kontakiotis EG, Wu MK, Wesselink PR. Effect of sealer thickness on long-term sealing ability: a 2-year follow-up study. Int Endod J. 1997;30:307-12.

13- Miranda RB, Fidel SR, Boller MA. L929 cell response to root perforation repair cements: an in vitro cytotoxicity assay. Braz Dent J. 2009;20:22-6.

14- Murata SS, Holland R, Souza V, Dezan-Junior E, Grossi JA, Percinoto $C$. Histological analysis of the periapical tissues of dog deciduous teeth after root canal filling with different materials. J Appl Oral Sci. 2005;13:318-24. 
15- Nunes ACGP, Rocha MJC. Hydroxyl and calcium ions diffusion from endodontic materials through roots of primary teeth - in vitro study. J Appl Oral Sci. 2005;13:187-92.

16- Oliveira RL, Oliveira-Filho RS, Gomes HG, Franco MF, Enokihara MM, Duarte MA. Influence of calcium hydroxide addition to AH Plus sealer on its biocompatibility. Oral Surg Oral Med Oral Pathol Oral Radiol Endod. 2010;109:e50-4.

17- Onay EO, Ungor M, Ozdemir BH. In vivo evaluation of the biocompatibility of a new resin-based obturation system. Oral Surg Oral Med Oral Pathol Oral Radiol Endod. 2007;104:e60-6.

18- Panzarini SR, Holland R, Souza V, Poi WR, Sonoda CK, Pedrini

D. Mineral trioxide aggregate as a root canal filling material in reimplanted teeth. Microscopic analysis in monkeys. Dent Traumatol. 2007;23:265-72.

19- Pinheiro CR, Guinesi AS, Camargo EJ, Pizzolitto AC, Filho IB. Bacterial leakage evaluation of root canals filled with different endodontic sealers. Oral Surg Oral Med Oral Pathol Oral Radiol Endod. 2009; 108:e56-60.

20- Peters LB, Wesselink PR. Periapical healing of endodontically treated teeth in one and two visits obturated in the presence or absence of detectable microorganisms. Int Endod J. 2002;35:6607.

21- Pommel L, About I, Pashley D, Camps J. Apical leakage of four endodontic sealers. J Endod. 2003;29:208-10.

22- Schilder H. Filling root canals in three dimensions. Dent Clin North Am. 1967;11:723-44.
23- Shipper G, Ørstavik D, Teixeira FB, Trope M. An evaluation of microbial leakage in roots filled with a thermoplastic synthetic polymer-based root canal filling materials (Resilon). J. Endod. 2004;30:342-7.

24- Silva-Neto UX, Moraes IG, Westphalen VP, Menezes R, Carneiro E, Fariniuk LF. Leakage of 4 resin-based root-canal sealers used with a single-cone technique. Oral Surg Oral Med Oral Pathol Oral Radiol Endod. 2007;104:e53-7.

25- Tanomaru-Filho M, Tanomaru JMG, Leonardo MR, Silva LAB. Periapical repair after root canal filling with different root canal sealers. Braz Dent J. 2009;20:389-95.

26- Torabinejad M, Smith PW, Kettering JD, Pitt Ford TR. Comparative investigation of marginal adaptation of mineral trioxide aggregate and other commonly used root-end filling materials. J Endod. 1995;21:295-9.

27- Torabinejad M, Watson TF, Pitt Ford TR. Sealing ability of an MTA when used as a root end filling material. J Endod. 1993;19:591-5.

28- Weller RN, Tay KCY, Garrett LV, Mai S, Primus CM, Gutmann $\mathrm{J}$, et al. Microscopic appearance and apical seal of root canals filled with gutta-percha and ProRoot Endo Sealer after immersion in a phosphate-containing fluid. Int Endod J. 2008;41:977-86. 29- Wennberg A, Ørstavik D. Adhesion of root canal sealers to bovine dentine and gutta-percha. Int Endod J. 1990;23:13-9.

30- Wu MK, Wesselink PR. Endodontic leakage studies reconsidered. Part I. Methodology, application and relevance. Int Endod J. 1993;26:37-43. 